\title{
Biological and morphometric aspects and rearing of Syssphinx molina (Cramer) (Lepidoptera: Saturniidae), a defoliator of parica tree
}

\author{
Telma Fátima Vieira BATISTA, Alexandre Mehl LUNZ², Valéria do Socorro Vale do ROSÁRIO1 \\ Leandro José Uchoa LEMOS ${ }^{1}$, Rodolfo Silva PROVENZANO ${ }^{1}$, Ernando da Silva MONTEIRO ${ }^{1}$
}

\section{ABSTRACT}

The objective of this research was to describe the biological and morphometric aspects of the parica tree defoliator, Syssphinx molina (Cramer), and make recommendations about the insect rearing. The life cycle was 62.9 days with mean periods for the egg, larval, pre-pupal and pupal stages of 5.6, 31.1, 2.2 and 16.6 days respectively. The pupal viability was $60.5 \%$ for females and $48.6 \%$ for males. The sexual ratio was 0.5 with mean production of $182.3 \pm 2.2$ eggs per female and egg viability of $24.3 \%$. The mean longevity was $7.9 \pm 2$ and $8.1 \pm 3$ days for females and males respectively. Other parameters were also observed and compared with description of other Saturniidae species.

KEYWORDS: Bionomy, life cycle, Neotropical, Schizolobium parahyba var. amazonicum.

\section{Aspectos biológicos e morfométricos e criação de Syssphinx molina (Cramer) (Lepidoptera: Saturniidae), desfolhadora de paricá}

\section{RESUMO}

O objetivo desse trabalho foi descrever os aspectos biológicos e morfométricos da lagarta desfolhadora do paricá, Syssphinx molina (Cramer), e fazer recomendaçóes para a criação do inseto. O ciclo de vida foi de 62,9 dias com períodos médios para as fases de ovo, lagarta, pré-pupa e pupa de 5,6; 31,1; 2,2 e 16,6 dias, respectivamente. A viabilidade das pupas foi de 60,5\% para fêmeas e 48,6\% nos machos. A razão sexual foi de 0,5 e a produção média de $182,3 \pm 2,2$ ovos por fêmea com viabilidade de ovos de 24,3\%. A longevidade média foi de 7,9 \pm 2 e 8,1 \pm 3 dias para fêmeas e machos, respectivamente. Outros parâmetros foram igualmente observados e comparados com a descrição de outras espécies de Saturniidae.

PALAVRAS-ChAVE: Bionomia, ciclo de vida, Neotropical, Schizolobium parahyba var. amazonicum.

${ }^{1}$ Inst. de Ciências Agrárias, Universidade Federal Rural da Amazônia (ICA/UFRA), Av. Tancredo Neves, 2501, Montese, Belém, PA, CEP 66077-530, telma.batista@ufra.edu.br

${ }^{2}$ Embrapa Amazônia Oriental, Lab. de Entomologia, Tv. Dr. Enéas Pinheiro, s/nº, Marco, Belém, PA, 66095-000, amehl@cpatu.embrapa.br 


\section{INTRODUCTION}

The parica tree, Schizolobium parahyba var. amazonicum (Huber ex Ducke) Barneby (Fabaceae), is a native species to the Amazon with rapid growth and its wood has an excellent use in foreign markets (IDEFLOR 2010) mainly in the plywood and laminates sectors and more recently as raw material for medium density fiberboard (MDF). The parica tree is the second native forestry species most cultivated in the country with roughly 90,000 ha in the states of Maranhão and Pará (ABRAF 2011).

The increase in cultivated areas with parica trees is directly proportional to the incidence of associated insects similarly to what occurred with the eucalyptus culture in the last century (Zanuncio et al. 1993). Among the insect species are fire ants (Lunz et al. 2009), wood flies (Lunz et al. 2010a) and cicadas (Zanuncio et al. 2004) being that cicadas present themselves as the main pest with unique assessment methodologies and control described for the parica tree crops (Lunz et al. 2010b). Currently, the defoliation caused by Lepidoptera is the second major cause of insect damage to parica tree crops in the state of Pará - Brazil.

Outbreaks of caterpillars have been reported in several municipalities in Pará (Galeão et al. 2005; Rosa 2006) especially in Dom Eliseu, Paragominas, Ulianópolis and Rondon do Pará, where from 2006 to 2010 a complex composed of three species of Lepidoptera defoliators has been reported and the damages caused by these species vary in terms of intensity and outbreaks constancy. The most common species was Syssphinx molina (Cramer, 1780) (Lepidoptera: Saturniidae) of wide geographic occurrence (Travassos 1940) commonly found in the Amazon, Atlantic Forest and Caatinga (Camargo 1997) mainly because of the incidence of several host plants such as Ficus retusa L. (Moraceae) and species of Acacia, Cassia and Inga (Fabaceae) (Silva et al. 1968). In one of the most affected areas in Paragominas (03⒊'976's; $48^{\circ} 50^{\prime} 449^{\prime \prime}$ W; alt. $103 \mathrm{~m}$ ), annual outbreaks of $S$. molina spread across areas ranging from 113 to 700 ha between 2004 and 2008. Defoliation was observed mainly during the rainy season in the region - December to May (EMBRAPA 1988) probably due to greater availability of leaves and branches resulting from the further development of the parica tree in this period.

S. molina occurs naturally in low amounts in primary and secondary forests and in areas reforested with Eucalyptus spp. (Hawes et al. 2009) with no economic relevance until the marked defoliation in parica tree crops. Therefore, given the importance of this species for the culture and the lack of information in literature on its development, this study aimed to investigate the main biological and morphometric aspects of $S$. molina and make recommendations regarding the insect rearing.

\section{MATERIALS AND METHODS}

The biological and morphometric analyses of S. Molina was developed in 2009 in the Laboratory of Entomology of the Universidade Federal Rural da Amazônia and of Embrapa Amazônia Oriental in the municipality of Belém, Pará-Brazil, from pupae collected in the municipality of Paragominas. The average temperature used was $25 \pm 2{ }^{\circ} \mathrm{C}$, relative humidity (RH) $74 \pm 10 \%$ and photophase $12 \mathrm{~h}$.

The pupae were sexed according to methodology adapted from Lorini (2008). Nine couples were placed in screened wooden cage $(1.0 \times 1.0 \times 1.0 \mathrm{~m})$ in the field under a shade and fed with glucose syrup at $30 \%$. The average temperature and $\mathrm{RH}$ in the period were $26^{\circ} \mathrm{C}$ and $89 \%$, respectively. The hatching, duration, height, diameter and average number of eggs per female for 16 days since the first laying were evaluated. Branches of parica trees, changed periodically at the first sign of wilting of leaves, packed in containers with water in the cages were used as egg-laying substrates.

In the laboratory, the larvae were fed with parica leaflets washed with sodium hypochlorite at $1 \%$, from plants older than one year of age, to obtain the height and width of head capsule, body size and instars duration. Leaves from plants with less than one year are inadequate for the rearing of $S$. molina larvae as they release a sticky exudate that prevents the locomotion of neonate larvae, killing them by starvation. In the field, defoliation in young crops is not observed, probably because of this defense mechanism of the plants.

The pupae were kept in screened wooden cages ( $30 \times 30$ $x 50 \mathrm{~cm}$ ) in Petri dishes with moistened filter paper discs to obtain the duration of the pre-pupal and pupal stages, color, weight and dimensions. In adults, the body length, thorax width between the points of insertion of the wings, antennae length, forewing length, hindwing width, abdominal width for the sixth abdominal segment and stature, calculated as the sum of the forewings length and the distance between the insertion points, were measured.

The statistical analyses were performed comparing the mean values of the parameters for males and females in the $t$ test at $5 \%$ probability through the Assistat 7.5 software (Silva and Azevedo 2006).

\section{RESULTS AND DISCUSSION}

Rearing and egg-laying. The egg-laying started three days after copulation (DAC) with a peak of 292 eggs on the eighth day. We obtained $102.5 \pm 2.3$ eggs per day and $182.3 \pm 2.2$ eggs per female. An increase of egg-laying on the fourth and eighth DAC and a reduction after the ninth day were observed (Fig. 1). Other species of Saturniidae have a greater egg-laying capacity, such as Eacles imperialis magnifica Walker, with an 




Figure 1- Daily egg-laying of nine couples of Syssphinx molina kept in screened wooden cages for 16 days. Belém, PA. 2009.

average of 193 eggs per female and Dirphia rosacordis Walker with 252 eggs per female, on average (Zanuncio et al. 1993).

Egg. The eggs were ellipsoid with flattened poles, light green in color even when newly laid similar to those observed in Copiopteryx semiramis (Cramer) (Lepidoptera: Saturniidae) (Furtado 2001), whitish and transparent after a few days, allowing the possible observation of the embryo. The laying is isolated or grouped. Infertile eggs become yellowish, shrink and dry out in a few days. The eggs hatched on average $5.6 \pm$ $1.25(\mathrm{n}=16)$ days after laying with an average of $2.7 \pm 0.32$ $\mathrm{mm}$ high and $2.0 \mathrm{~mm}$ of core diameter $(\mathrm{n}=45)$, values higher than those of eggs of L. obliqua, with height of $1.98 \pm 0.687$ $\mathrm{mm}$ and a diameter of $1.45 \pm 0.129 \mathrm{~mm}$ (lower) and 1.61 $\pm 0.161 \mathrm{~mm}$ (larger) (Lorini and Corseuil 2001). The low viability of eggs $(24.3 \%)$ can be attributed to the nutritional aspect of feed.

Larva. Five instars were observed in S. molina, similar to other Saturniidae such as Philosamia ricini (Drury) (Santos et al. 2000) and Rothschildia jacobaeae (Walker) (Urban and Oliveira 1972), however different from Automeris naranja Schaus (Specht et al. 2007a) and A. illustris (Walker) (Specht et al. 2006), both with six instars and Hylesia metapyrrha (Walker) with seven (Specht et al. 2007b).

The height and width of head capsule ranged, respectively, from $1.9 \pm 0.20$ to $1.1 \pm 0.10 \mathrm{~mm}$ for the first instar and from $5.0 \pm 0.32$ to $4.0 \mathrm{~mm}$ for the fourth instar. The dimensions of the capsules of the fifth instar were not obtained due to the deformity caused by the transition to the pupal stage. The body length ranged from $0.6 \pm 0.01$ to $4.6 \pm 0.13 \mathrm{~mm}$ from the first to the fifth larval instar, respectively (Table 1). The average duration of larval stage was $31.1 \pm 5.22$ days. The larval survival rate was only $38.4 \%$ considered low compared with other Saturniidae such as $95.6 \%$ in $A$. naranja (Specht $e t$ al. 2007a), $82 \%$ in E. i. magnifica and $88 \%$ in D. rosacordis (Zanuncio et al. 1993). The diet consisted solely of parica tree leaflets probably caused the low survival rate despite its
Table 1 - Average height and width of the head capsule and average length of the larvae bodies $(n=15)$ of Syssphinx molina, in laboratory. Temperature: $25 \pm 2^{\circ} \mathrm{C} ; \mathrm{RH}: 70 \pm 10 \%$ and photoperiod $12 \mathrm{~h}$. Belém, PA. 2009.

\begin{tabular}{lcccccc}
\hline \multirow{2}{*}{ Instar } & \multicolumn{2}{c}{ Height $(\mathrm{mm})$} & \multicolumn{2}{c}{ Width $(\mathrm{mm})$} & \multicolumn{2}{c}{ Body length $(\mathrm{cm})$} \\
\cline { 2 - 7 } & Average & $\begin{array}{c}\text { Standard } \\
\text { Error }\end{array}$ & Average & $\begin{array}{c}\text { Standard } \\
\text { Error }\end{array}$ & Average & $\begin{array}{c}\text { Standard } \\
\text { Error }\end{array}$ \\
\hline First & 1.9 & 0.20 & 1.1 & 0.10 & 0.6 & 0.01 \\
Second & 2.7 & 0.36 & 2.0 & 0.00 & 1.2 & 0.02 \\
Third & 3.7 & 0.47 & 2.8 & 0.20 & 1.8 & 0.06 \\
Fourth & 5.0 & 0.32 & 4.0 & 0.00 & 2.8 & 0.06 \\
Fifth & - & - & - & - & 4.6 & 0.13 \\
\hline
\end{tabular}

daily replacement due to the rapid wilting of the leaves after collection.

First instar: Yellow-green coloration and body covered with small non-stinging bristles with eight thoracic spines and an anal cornicle as large as or larger than the body, whose apices are spherical reddish; two pairs of spines on the sides of the dorsum of mesothorax and two pairs in the metathorax; other smaller spines equidistant along the thoracic spines. Epicranial suture well visible dividing the superior head capsule into two regions. The average duration was $4.8 \pm 0.90$ days $(\mathrm{n}=18)$.

Second and third instars: Green head in the second instar; green-colored body and the longitudinal continuous greenish-yellow lines on the sides, where nine spines vestigial are inserted; robust thoracic spines. The body length is $1.2 \mathrm{~cm}$ $\pm 0.02(\mathrm{n}=18)$. In the third instar, the thoracic spines and the caudal cornicle decrease and the spherical apex disappear. The average duration was $4.1 \pm 1.30$ and $5.3 \pm 1.20$ days $(\mathrm{n}=$ 18) for the second and third instars, respectively.

Fourth and fifth instars: Light-green colored body in the fourth instar, covered with small yellow spots, with continuous lateral longitudinal line without spikes. Caudal cornicle and thoracic spines reduced in the fourth instar and virtually absent in the fifth instar. Presence of a pair of robust spines, broad and jagged, white in color, on the back of the VII and IX segments of the fourth instar that become vestigial in the fifth instar. In the fifth instar, blue spots along the body and greenish legs of the last abdominal segment with large and prominent hooks. The average duration was $5.2 \pm 0.80$ and $11.8 \pm 1.00$ days $(n=18)$ for the fourth and fifth instars, respectively. At the end of the fifth instar, the larvae reduced movements and shrank the body became blackened and featuring the pre-pupal duration of $2.2 \pm 1.12$ days $(\mathrm{n}=18)$.

Pupa. Naked, obtect with double layer of bristles between the abdominal segments and a long jagged cremaster with a forked end (Fig. 2A-B), dark brown to black colored, matte and with hard integument. For sexing, the characteristics 
of abdominal segments VIII and IX were determinants in addition to body size. While in the female the abdominal segment IX extends into segment VIII, which will become the apertures for copulation and egg-laying, however, the same does not occur in males (Fig. 2C-D). Female pupae were significantly larger than those of males in terms of width, length and body weight (Table 2). The pupal duration was $16.6 \pm 2.26$ days, the pupal viability was $60.52 \%$ in females $(\mathrm{n}=38)$ and $48.57 \%$ in males $(\mathrm{n}=35)$.
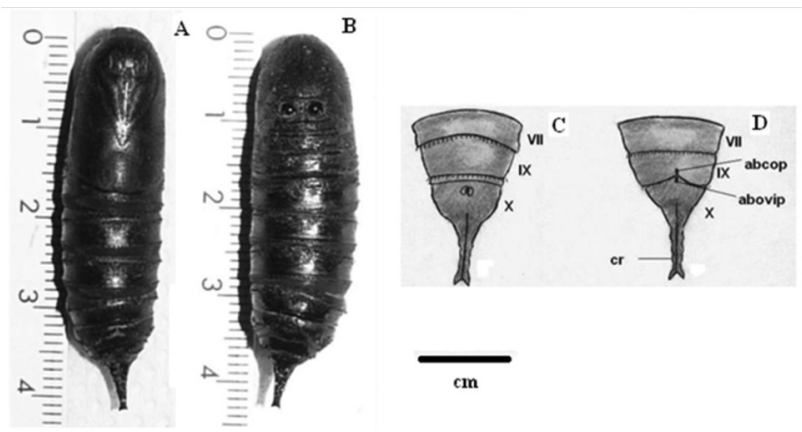

Figure 2 - Ventral (A) and dorsal (B) views of pupae of Syssphinx molina with details for the ventral apex segments of the male (c) and female (d), highlighting the last abdominal segments (VII, IX and X), the cremaster (cr) and the origin of aperture for copulation (abcop) and egg-laying (abovip). The horizontal bar $=1 \mathrm{~cm}$.

Table 2 - Averages of length, width and weight of pupae of Syssphinx molina under laboratory conditions $(n=35)$. Belém, PA. 2009.

\begin{tabular}{lcccccc}
\hline & \multicolumn{2}{c}{ Length $(\mathrm{mm})$} & \multicolumn{2}{c}{ Width $(\mathrm{mm})$} & \multicolumn{2}{c}{ Weight $(\mathrm{g})$} \\
\cline { 2 - 7 } Sex & Average & $\begin{array}{c}\text { Standard } \\
\text { error }\end{array}$ & Average & $\begin{array}{c}\text { Standard } \\
\text { error }\end{array}$ & Averaga & $\begin{array}{c}\text { Standard } \\
\text { error }\end{array}$ \\
Male & $43.5 \mathrm{~b}$ & 0.27 & $10.8 \mathrm{~b}$ & 0.01 & $4.1 \mathrm{~b}$ & 0.10 \\
Female & $46.7 \mathrm{a}$ & 0.27 & $11.6 \mathrm{a}$ & 0.01 & $5.3 \mathrm{a}$ & 0.10 \\
\hline
\end{tabular}

Adult. Light-beige colored wings and body (Fig. 3) with high concentration of scales especially in the head and thorax; the pair of forewings in males has fine transverse dark midrib ranging from costal margin to the anal, while females have two very clear transverse ribs, blackened maculae on the rear faces of the forewings and on the front faces of the hind wings and being partly and completely surrounded by a pinkish spot in the first and second cases, respectively.

Sexual dimorphism was sharp in all parameters except in the antennae length (Table 3). The mating behavior observed was similar to L. obliqua (Lorini 2008), with single copulation and duration over 24 hours preceded by a courtship with several flights to the prenuptial until copulation. The average life cycle was $7.9 \pm 2$ and $8.1 \pm 3$ days $(n=9)$ in females and males, respectively, values similar to those described for other Saturniidae, such as H. metapyrrha 5.5 (Specht et al. 2007b), L. obliqua with 6.8 (Lorini and Corseuil 2001), A. naranja

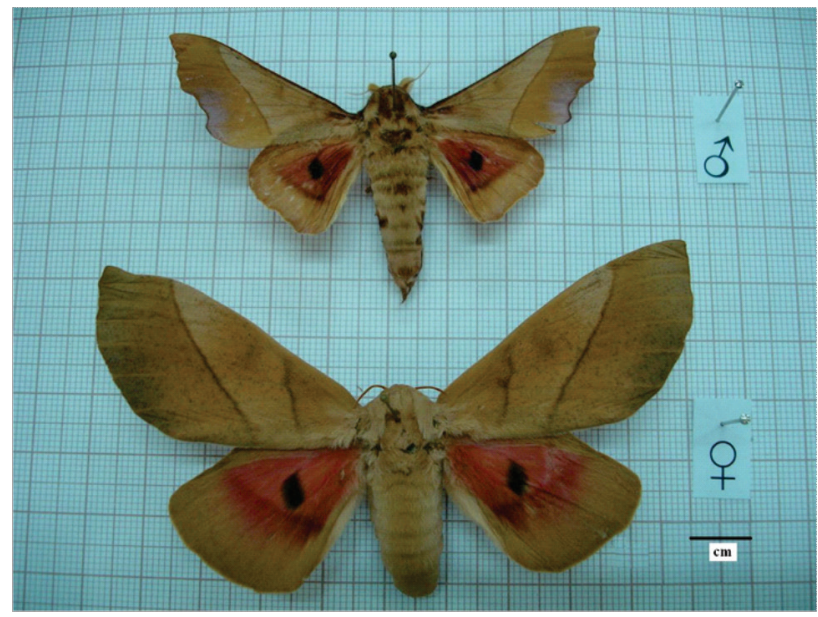

Figure 3- Male (above) and female (below) of Syssphinx molina obtained from a rearing in laboratory. Belém, PA. 2009. The horizontal bar $=1 \mathrm{~cm}$.

Table 3 - Measurements of adults of Syssphinx molina under laboratory conditions. Belém, PA. 2009.

\begin{tabular}{lcccccc}
\hline \multirow{2}{*}{$\begin{array}{l}\text { Measurements } \\
(\mathrm{mm})\end{array}$} & \multicolumn{3}{c}{ Female } & \multicolumn{4}{c}{ Male } \\
\cline { 2 - 7 } & $\mathrm{n}$ & Mean & $\begin{array}{c}\text { Standard } \\
\text { error }\end{array}$ & $\mathrm{n}$ & Mean & $\begin{array}{c}\text { Standard } \\
\text { error }\end{array}$ \\
\hline Fore wing length & 9 & $44.67 \mathrm{a}$ & 1.41 & 9 & $26.67 \mathrm{~b}$ & 1.02 \\
\hline Thorax width & 9 & $10.94 \mathrm{a}$ & 0.62 & 9 & $9.00 \mathrm{~b}$ & 0.50 \\
\hline Wing length & 9 & $99.00 \mathrm{a}$ & 2.97 & 9 & $59.11 \mathrm{~b}$ & 1.29 \\
\hline Body length & 9 & $36.33 \mathrm{a}$ & 0.95 & 9 & $32.67 \mathrm{~b}$ & 0.50 \\
\hline Abdomen length & 9 & $11.78 \mathrm{a}$ & 0.69 & 9 & $7.33 \mathrm{~b}$ & 0.50 \\
\hline Antennae length & 7 & $9.00 \mathrm{a}$ & 0.69 & 9 & $7.33 \mathrm{a}$ & 0.41 \\
\hline Hind wing width & 9 & $29.11 \mathrm{a}$ & 1.75 & 9 & $18.89 \mathrm{~b}$ & 0.48 \\
\hline
\end{tabular}

Means followed by different letters in the columns differ significantly in the $t$ test $5 \%$ probability. $\mathrm{n}=$ number of individuals measured for each sex.

with 7.6 (Specht et al. 2007a) and Citheronia brissotii brissotii (Boisduval) at nine days (Fronza et al. 2005). The sex ratio of 0.5 was similar to that obtained for A. illustris of 0.505 (Specht et al. 2006).

There is variation in the life cycle of adults of other Saturniidae when fed with alternative diet as seen in Dirphia moderata Bouvier, whose males lasted 8.84 and 6.78 days and the females, 10.23 and 10.07 days when fed on leaves of Eucalyptus cloeziana F. Muell. and Psidium guajava L. (Myrtaceae), respectively (Pereira et al. 2008). The use of leaves of alternative hosts of $S$. molina and tests with artificial diets can provide a reduction in mortality especially in the first instar and optimize the results to enable rearing for further research on the outbreak control for parica trees crops.

The life cycle of $S$. molina was $62.9 \pm 2.12$ days $(\mathrm{n}=45)$, smaller than that obtained in other Saturniidae such as $H$. metapyrrha with 74.59 days (Specht et al. 2007b), A. illustris, 
with 121 days (Specht et al. 2006), A. naranja, with 128 days (Specht et al. 2007a) and C. b. brissotii with 202 days (Fronza et al. 2005), which demonstrates the potential for rearing $S$. molina in laboratory at large amounts and in less time than other species.

This is the first record of biological and morphometric S. molina, the major defoliator of parica tree crops and the results allow to establish management strategies and identification of the insect in the field. We recommend the use of nutritionally-rich food substrates for adults to check the egg-viability increase; tests with leaves of alternative host plants and artificial diets as food substrate to observe the increase in larval survival of $S$. molina reared in laboratory and studies of possible influence of different photoperiods and temperatures on the biology and behavior of the insect.

\section{ACKNOWLEDGEMENTS}

We wish to thank the agronomist André Cortez Mahon for the operational and logistic support in the field works. We also thank Cikel Brasil Verde Madeiras Ltda. for authorizing the use of the area and the collecting of insects. We thank the Fundação de Amparo à Pesquisa do Estado do Pará (Fapespa) for the financial support (Proclamation No. 003/2008).

\section{REFERENCES}

ABRAF. 2011. Anuário estatístico da Associação Brasileira de Produtores de Florestas Plantadas 2011: ano base 2010. ABRAF, Brasília, Distrito Federal. 130pp.

Camargo, A.J.A. 1997. Relaçôes biogeográficas e influência da estação seca na distribuição de mariposas da família Saturniidae (Lepidoptera) da região dos Cerrados. Dissertação de Mestrado, Universidade de Brasília, Brasília, Distrito Federal. 116 pp.

EMBRAPA. 1988. Centro de Pesquisa Agropecuária do Trópico Úmido. Laboratório de Climatologia. Normais climatológicas de Paragominas no periodo de 1980 a 1988. CPATU, Belém, Pará.

Fronza, E.; Formentini, A.C.; Specht, A.; Corseuil, E. 2005. Aspectos biológicos de Citheronia brissotii brissotii (Lepidoptera, Saturniidae, Ceratocampinae), em laboratório. Biociências, 13: 143-148.

Furtado, E. 2001. Copiopteryx semiramis (Cramer): notas suplementares à sua biologia (Lepidoptera, Saturniidae, Arsenurinae). Revista Brasileira de Zoologia, 18: 637-640.

Galeão, R.R.; Marques, L.C.T.; Yared, J.A.G., Ferreira, C.A.P. 2005. Paricá (Schizolobium amazonicum Huber): espécie florestal de uso múltiplo com alto potencial para reflorestamento na Amazônia brasileira. Revista de Ciências Agrárias, 44: 157-162.

Hawes, J.; Motta, C.S. Overal, W.L.; Barlow, J.; Gardner, T.A.; Peres, C.A. 2009. Diversity and composition of Amazonian moths in primary, secondary and plantation forests. Journal of Tropical Ecology, 25: 281-300.
IDEFLOR. 2010. Plano Safra Florestal Madeireira do Estado do Pará: 2010. Instiuto de Desenvolvimento Florestal do Pará, Belém, Pará. 102 pp.

Lorini, L.M.; Corseuil, E. 2001. Aspectos morfológicos de Lonomia obliqua Walker (Lepidoptera, Saturniidae). Neotropical Entomology, 30: 373-378.

Lorini, L.M. 2008. Saturniidae Hemileucinae Lonomia obliqua Walker, 1855, p. 165-185. In: Specht, A; Corseuil, E.; Abella, H.B. (Eds.) Lepidópteros de importância médica - Principais espécies ocorrentes no Rio Grande do Sul. USEB, Pelotas, Rio Grande do Sul.

Lunz, A.M.; Harada, A.Y.; Aguiar, T.S.; Cardoso, A.S. 2009. Danos de Solenopsis saevissima F. Smith. (Hymenoptera: Formicidae) em paricá, Schizolobium amazonicum. Neotropical Entomology, 38: 285-288.

Lunz, A.M.; Batista, T.F.C.; Rosário, V.S.V.; Monteiro, O.M.; Mahon, A.C. 2010a. Ocorrência de Pantophthalmus kerteszianus e P. chuni (Diptera: Pantophthalmidae) em paricá, no Estado do Pará. Pesquisa Florestal Brasileira, 30: 71-74.

Lunz, A.M.; Azevedo, R.; Mourão Júnior, M.; Monteiro, O.M.; Lechinoski, A.; Zaneti, L.Z. 2010b. Método para monitoramento de ninfas de cigarras e controle com inseticidas em reflorestamentos com paricá. Pesquisa Agropecuária Brasileira, 45: 631-637.

Pereira, F.F.; Zanuncio, A.J.V.; Felipe, J.P.M.; Lorenzon, A.S.; Canevari, G.C. 2008. Desenvolvimento e reprodução de Dirphia moderata (Lepidoptera: Saturniidae) em Eucalyptus cloeziana e Psidium guajava em laboratório. Árvore, 32: 1119-1124.

Rosa, L.S. 2006. Ecologia e silvicultura do paricá (Schizolobium amazonicum Huber ex Ducke) na Amazônia brasileira. Revista de Ciências Agrárias, 45: 135-174.

Santos, S.C.L.; Filgueira, M.A.; Santos, J.H.R.; Leshan, H. 2000. Aspectos biológicos de Philosamia ricini (Drury, 1777) (Lep.: Saturniidae) em Mossoró, RN. Caatinga, 13: 7-13.

Silva, A.G.A.; Gonçalves, C.R.; Galvão, D.M. 1968. Quarto catálogo dos insetos que vivem nas plantas do Brasil, seus parasitos e predadores. Parte II, $1^{\circ}$ tomo. Insetos, hospedeiros e inimigos naturais. Ministério da Agricultura, Rio de Janeiro, Rio de Janeiro. 622pp.

Silva, F.A.S.E.; Azevedo, C.A.V. 2006. New Version of The AssistatStatistical Assistance Software, p. 393-396. In: World Congress on Computers in Agriculture, 4, Florida, EUA. Anais... American Society of Agricultural Engineers, Orlando, USA.

Specht, A., Formentini, A.C. Corseuil, E. 2006. Biologia de Automeris illustris (Walker) (Lepidoptera, Saturniidade, Hemileucinae). Revista Brasileira de Zoologia, 23: 537-546.

Specht, A., Formentini, A.C. Corseuil, E. 2007a. Biologia e aspectos morfológicos dos estágios imaturos de Automeris naranja Schaus (Lepidoptera, Saturniidae, Hemileucinae). Revista Brasileira de Zoologia, 24: 523-534.

Specht, A., Formentini, A.C. Corseuil, E. 2007b. Biological aspects of Hylesia metapyrrha (Lepidoptera; Saturniidae; Hemileucinae), in laboratory. Brazilian Journal of Biology, 67: 173-177. 
Travassos, L. 1940. Adelocefalídeos do Estado de Mato Grosso, capturados pela expedição do Instituto Oswaldo Cruz. Memórias do Instituto Oswaldo Cruz, 35: 577-603.

Urban, D.; Oliveira, B.L. 1972. Contribuição ao conhecimento da biologia de Rothschildia jacobaeae (Lepidoptera: Saturniidae). Acta Biológica Paranaense, 1: 35-49.

Zanuncio, J.C.; Santana, D.L.Q.; Nascimento, E.C.; Santos, G.P.; Alvez, J.B.; Sartório, R.C.; Zanuncio, T.V. 1993. Lepidoptera desfolhadores de eucalipto: biologia, ecologia e controle. IPEF/SIF, Viçosa, Minas Gerais. 140pp.

Zanuncio, J.C.; Pereira, F.F.; Zanuncio, T.V.; Martinelli, N.M.; Pinon, T.B.M.; Guimarães, E.M. 2004. Occurrence of Quesada gigas on Schizolobium amazonicum trees in Maranhão and Pará states, Brazil. Pesquisa Agropecuária Brasileira, 39: 943-945.

Recebido em :17/11/2012

Aceito em: 04/04/2012 